Case report

\title{
Multiple large atrial thrombus due to rheumatic heart disease and present of atrial fibrillation with no sign of stroke: how is it possible?
}

Ricky Indra Alfaray ${ }^{1}$, Deisha Lakshmitha Ayomi ${ }^{2}$, Yan Efrata Sembiring ${ }^{3}$

1,2) Faculty of Medicine Airlangga University

3) Department of Thoracic and Cardiovascular Surgery, Faculty of Medicine Airlangga University

A R T I C L E I N F O

\begin{tabular}{ll}
\hline Submitted & : January 2019 \\
Accepted & : May 2019 \\
Published & : July 2019
\end{tabular}

Keywords:

atrial fibrillation, rheumatic heart disease, thromboembolism stroke

\section{Correspondence:}

rickyindraalfaray@gmail.com

\begin{abstract}
Atrial fibrillation is the most common arrhythmia associated with stroke and in the rheumatic heart disease patient's atrial fibrillation can easily cause thromboembolism. Thromboembolism is the major complication also in patients of mitral stenosis with atrial fibrillation. A 54-year-old woman with uncontrollable movements in the right arm, stomach, right leg and painful swelling at right ankle joint was admitted to the emergency department. Transesophageal echocardiogram revealed rheumatic heart disease affecting two valves and thrombus in left atrial extending towards left atrial appendage. Heart rate was 120 beats per minute. ECG showed atrial fibrillation. A patient has undergone mitral and aortic valves replacement surgery and left atrial thrombus evacuation. Despite the involvement of two heart valves and the presence of large thrombus, the patient did not show any sign of brain infarction. This is a contradiction with a theory which implies that atrial fibrillation is the most common arrhythmia associated with stroke and in the rheumatic heart disease patient's atrial fibrillation can easily cause thromboembolism and become stroke. This study evaluates many factors founded in the patient that make this anomaly may happen.
\end{abstract}


ABSTRAK

Atrial fibrilasi merupakan jenis aritmia yang berkaitan erat dengan stroke dan cenderung menyebabkan thromboembolism. Thromboembolism merupakan komplikasi mayor dari mitral stenosis dengan atrial fibrilasi. Seorang wanita berusia 54 tahun masuk ke unit gawat darurat dengan keluhan utama gerakan tak terkendali pada lengan kanan, perut, kaki kanan, serta bengkak yang menyakitkan di sendi pergelangan kaki kanan. Echocardiogram transesophageal menunjukan gambaran penyakit jantung rematik pada dua katup dan trombus di atrium kiri meluas menuju valve atrium kiri. Detak jantung 120 kali per menit. EKG menunjukkan fibrilasi atrium. Pasien menjalani operasi penggantian katup mitral dan aorta serta evakuasi trombus pada atrium. Meskipun terdapat abnormalitas pada dua katup jantung ditambah dengan ditemukan adanya trombus besar pada atrium, pasien tidak menunjukkan tanda-tanda infark otak. Ini bertentangan dengan teori yang mengimplikasikan bahwa atrial fibrilasi adalah aritmia paling umum yang berhubungan dengan stroke dan pada penyakit jantung reumatik. Pasien dengan fibrilasi atrium dapat dengan mudah terjadi tromboemboli hingga bermanifestasi stroke. Studi ini mengevaluasi berbagai faktor yang memungkinkan anomali kasus seperti ini dapat terjadi.

Kata kunci : fibrilasi atrium, penyakit jantung rematik, stroke thromboemboli

\section{INTRODUCTION}

Rheumatic heart disease is an uncommon health problem in developing countries. Most patients belong to low socioeconomic class and lack proper healthcare. Atrial fibrillation is the most common arrhythmia associated with stroke and in the rheumatic heart disease patient's atrial fibrillation can easily cause thromboembolism. Thromboembolism is the major complication also in patients of mitral stenosis with atrial fibrillation. Studies have revealed that controlling heart rate has significantly decreased the hypercoagulable state and thus decreased the risk of thromboembolism. With proper heart rate control, it is possible to decrease the dose of oral anticoagulants because controlling of ventricular rate in patients with concomitant (AF and MS) produces significant alighting inactivation of the coagulation system (Yusuf et al., 2015). Hence we decided to present a case report about rheumatic heart disease with mitral stenosis and atrial fibrillation as manifestations.

\section{CASE REPORT \\ CASE PRESENTATION}

We present a case of a 54-year-old woman presented to the emergency department after experiencing uncontrollable movements of her right arm for three weeks. Afterward, the continuous uncontrollable movements spread to her abdomen and to the right leg. One week prior to hospital admission, the patient also developed painful right ankle swelling. She admitted taking NSAIDs without any effect. The patient had a sore throat one month before hospital admission and reported the history of occasional irregular heart rate. Her medications included bisoprolol, digoxin, furosemide, and spironolactone, which were started three years ago with undisclosed indication. The patient denied a history of diabetes mellitus.

\section{INVESTIGATIONS}

On examination, the heart rate was 120 beats per minute. The results of language testing, cranial nerve, and motor system examinations were normal. There were continuous involuntary movements of her right arm, abdomen, and 


\section{QANUN MEDIKA JURNAL KEDOKTERAN FK UM SURABAYA \\ http://journal.um-surabaya.ac.id/index.php/qanunmedika}

right leg. On heart auscultation, there was a diastolic murmur loudest at the apex.

On admission, potassium, blood sugar, blood urea nitrogen and creatinine levels were high. The values normalized shortly after admission. The complete blood count remained normal throughout the hospitalization. The total cholesterol, low-density lipoprotein, triglyceride levels were high. The ECG demonstrated atrial fibrillation with a rapid ventricle response.

Transesophageal echocardiogram and echocardiogram revealed severe mitral stenosis, mild aortic and tricuspid stenosis, and mild tricuspid regurgitation. Thrombus in left atrium $(3,5 \times 2,6$ centimeters) extending towards left atrial appendage $(2,2 \times 1,4$ centimeters $)$. The atrial septum remained intact. The contractility and the systolic function of the left ventricle were normal (ejection fraction was 66\%). The Coronary angiography diagnostic did not indicate any sign of coronary heart disease. Chest x-ray revealed cardiomegaly. A CT scan of the head showed no sign of brain infarction (figures 1-3).

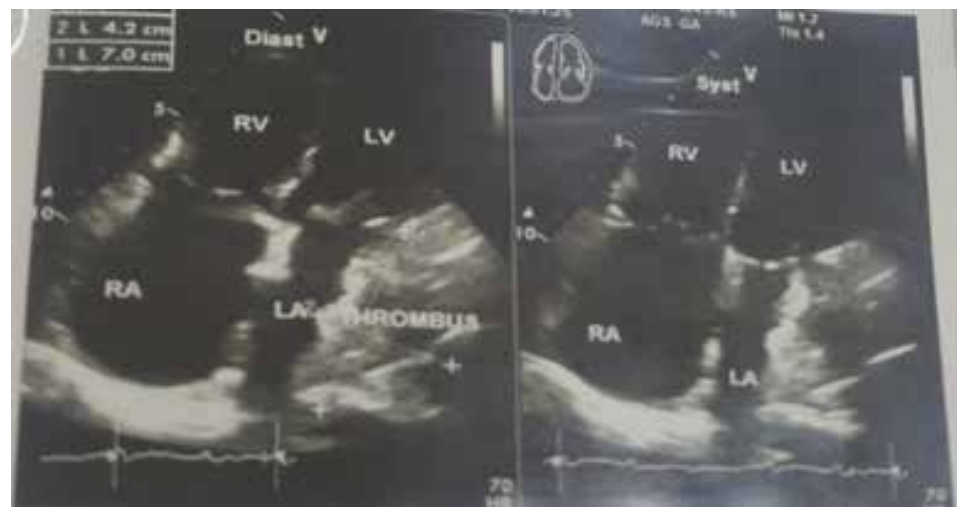

Figure 1. This image demonstrates thrombus in left atrium extending towards left atrial appendage

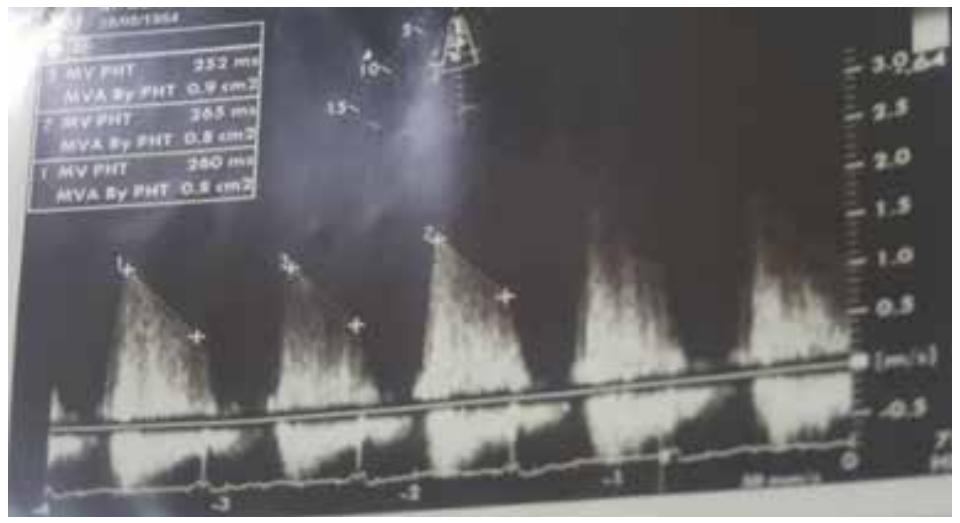

Figure 2. Mitral inflow continuous (cw) doppler profile. This image demonstrates severe mitral stenosis (a mean pressure gradient $>10 \mathrm{mmHg}$ ). Four chamber view of the heart at the top of the image demonstrates dilatation of left atrium, pulmonary artery, right ventricle, and right atrium. 


\section{QANUN MEDIKA \\ JURNAL KEDOKTERAN FK UM SURABAYA \\ http://journal.um-surabaya.ac.id/index.php/qanunmedika}

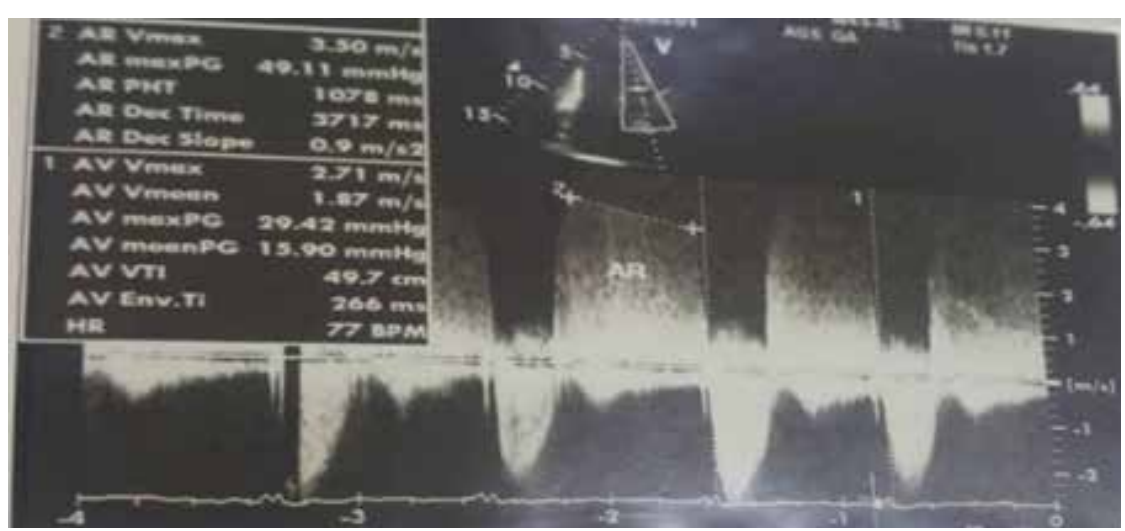

Figure 3. Aortic continuous wave (cw) doppler profile. This image demonstrates the increased pressure gradient indicating severe aortic stenosis

\section{TREATMENT}

The diagnosis of severe mitral and mild aortic stenosis as complications of rheumatic heart disease and multiple thrombi in left atrial extending towards left atrial appendage was made. Multiple medications were started digoxin $0,25 \mathrm{mg}$ and spironolactone in the morning and bisoprolol $5 \mathrm{mg}$ at night orally. The patient underwent aortic and mitral valve replacement and left atrial thrombus evacuation surgery with median sternotomy and cardiopulmonary bypass. The aortic valve was replaced with an $18 \mathrm{~mm}$ ATS-Medtronic and the mitral valve with a $25 \mathrm{~mm}$ ATSMedtronic valve. The atrial thrombus was successfully evacuated.

\section{OUTCOME AND FOLLOW-UP}

There were no significant postoperative complications and the patient was discharged 9 days after the operation. Post-operative transesophageal echocardiogram revealed functional mechanical aortic and mitral valves without any sign of valvular and paravalvular leakage. There was no thrombi present. The ejection fraction was $67 \%$ (figures $4-6$ )

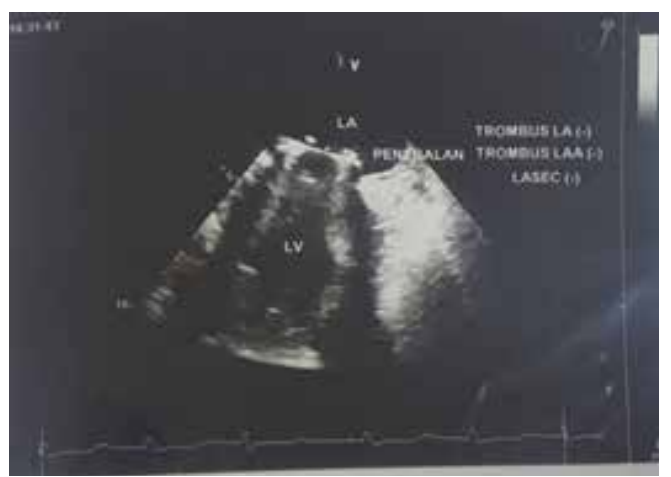

Figure 4. this image reveals absence of thrombus in left atrium and left atrial appendage 


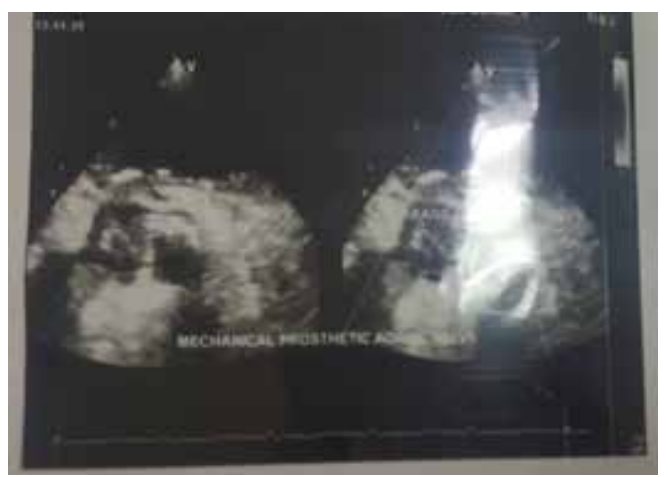

Figure 5. This images demonstrates functional mechanical mitral valves without any sign of valvular and paravalvular leakage.

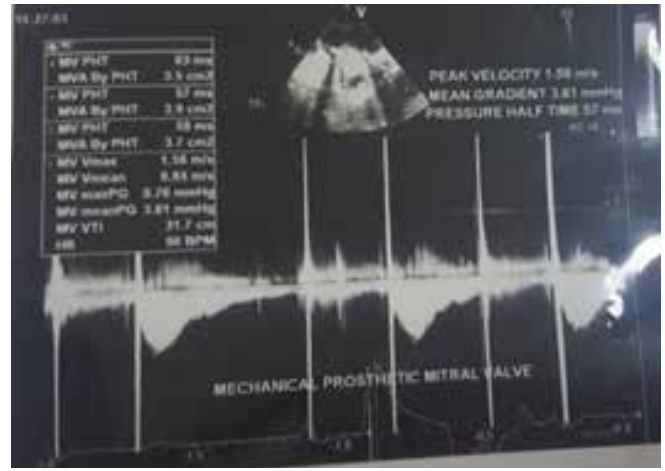

Figure 6. Aortic continous wave (cw) doppler profile. This image demonstrates decreased pressure gradient.

\section{DISCUSSION}

The incidence of AF in patients with RHD is $43.61 \%$ (Pradhan et al., 2018). In Southeast Asia, $8 \%$ of patients with AF die because of stroke (Healey et al., 2016).

A study suggests that Atrial Fibrillation (AF) is probably the most common arrhythmia associated with stroke in the RHD patients and that the presence of subclinical AF is often a cause of systemic thromboembolism (Gupta et al., 2015). A persistent, with or without RHD, is a risk factor for thrombi formation due to the induction of hypercoagulable state. Furthermore, in this case, the patient also has severe Mitral Stenosis (MS) which also can be a risk factor of thrombi formation. A theory shows the mechanism that explains the prothrombotic state in MS is an obstruction to flow past the mitral valve. The obstruction leads to increased pressure in the left atrium (LA) and blood stasis, then stimulate platelets activation also coagulation system. Thus, our predisposition to thrombus formation (Phankingthongkum et al., 2004). Patients who have concomitant diagnose MS with AF, have a risk of stroke 17 times than patients with the non-valvular disease. It is speculated that almost $90 \%$ of heart thrombi result in stroke, and the blood clots originate in a pouch on the left side of the heart called left atrial appendage (Lee et al., 2010). Another data shows that Cardioembolic stroke accounts for $14-30 \%$ of all cerebral infarctions (Arboix and Alio, 2010). Thrombi from the left heart flow through the arc of the aorta into the carotid artery and continue to the cerebral circulation, where they obstruct smaller arteries causing hypoxia of the 
cerebral tissue, resulting in ischemic stroke. The most common location of the embolism is cerebral medial artery (Helgason, 1992; Airlangga, 2017). In this case report, even though the patient had multiple emboli, there was no sign of ischemic stroke. According to epidemiology, it was clear that this case is included in hard-to-find cases.

According to the national practice guidelines for cardiac disease by Indonesian Cardiologist Association, RHD patient should be assessed with echocardiography, complete blood analysis, chest X-ray, transthoracic and transesophageal echocardiography and coronary angiography (if the patient $>40$ years old). RHD patients should receive medication to control heart rate (digoxin, bisoprolol, digitalis), diuretics (hydrochlorothiazide, furosemide, spironolactone), electrolyte supplements (oral potassium), anticoagulant (warfarin) and antiarrhythmic medication (amiodarone). Some of the patients with RHD might also require cardiosurgical interventions such as heart valve replacement or thrombus evacuation (Indonesian Cardiologist Association, 2016).

In the present case, a transesophageal echocardiogram revealed rheumatic heart disease affecting two valves and thrombus in the left atrium extending towards left atrial appendage. ECG showed atrial fibrillation. The longest diameter of the thrombus was $3,5 \times 2,6$ centimeters. The presence of such a thrombus should almost certainly result in stroke however, we did not discover any sign of significant brain ischemia. The possible explanation for this rare case might be that the large diameter of the giant thrombus, thus prevented it from migrating into cerebral circulation or systemic circulation. A previously published study showed that there was a different clinical presentation for a patient with thromboembolism whether in brain or systemic. The clinical presentation mainly depends on the size and consistency of thrombus (Deora et al., 2014). Second, the patient consumed anticoagulant routinely, and it is proven to successfully prevent ischemic stroke in a patient with RHD and AF (Topcuoglu et al., 2018, Ha et al., 2017). This is in line with another similar case report which concludes that RHD patient with AF did not suffer from ischemic stroke because of history of taking the anticoagulant medication as prevention of stroke. The anticoagulant agent that can be used as the first-line choice is Warfarin. Warfarin, described as a vitamin $\mathrm{K}$ antagonist (VKA), has been the standard therapy to prevent thromboembolism formation in patients with AF (Camm et al., 2010, Camm et al., 2012, Ha et al., 2017, Ahmad and Wilt, 2016). Third, the patient also consumed beta-blocker agent dan digoxin. Beta-blocker agents can inhibit thrombus formation indirectly which means that beta-blocker agents also can decrease the risk of stroke. It is due to its capability to increase the diastolic filling time. When the heart rate decrease, the diastolic filling time increases, and this phenomenon results in a decrease of a transmitral gradient, LA pressure and blood stasis in the atrium. Digoxin's role in decreasing heart rate by reducing the electrical impulses. It can also strengthen heart contractions (Yusuf et al., 2015).

\section{CONCLUSION}

Rheumatic heart disease is a common health problem in developing countries. Most patients are admitted late with already developed complications and require surgical intervention. Controlling the ventricular rate in patients with atrial fibrillation and mitral stenosis might decrease the risk of systemic thromboembolism. 


\section{REFERENCES}

Ahmad, S \& Wilt, H 2016. Stroke Prevention in Atrial Fibrillation and Valvular Heart Disease. Open Cardiovasc Med J, 10, 1106.

Airlangga, MP. 2017. Tinjauan kepustakaan: Diagnosis dan Tatalaksana Tromboemboli pada Kehamilan. Qanun Medika vol 1(2).

Arboix, A. \& Alio, J. 2010. Cardioembolic stroke: clinical features, specific cardiac disorders and prognosis. Curr Cardiol Rev, 6, 150-61.

Camm, A. J., Kirchhof, P., Lip, G. Y., Schotten, U., Savelieva, I., Ernst, S., van Gelder, I. C., Al-attar, N., Hindricks, G., Prendergast, B., Heidbuchel, H., Alfieri, O., Angelini, A., Atar, D., Colonna, P., de Caterina, R., de Sutter, J., Goette, A., Gorenek, B., Heldal, M., Hohloser, S. H., Kolh, P., le Heuzey, J. Y., Ponikowski, p., Rutten, f. H. \& Guidelines, e. S. C. C. F. P. 2010. Guidelines for the management of atrial fibrillation: the Task Force for the Management of Atrial Fibrillation of the European Society of Cardiology (ESC). Europace, 12, 1360-420.

Camm, A. J., Lip, G. Y., de Caterina, R., Savelieva, I., Atar, D., Hohnloser, S. H., Hindricks, G., Kirchhof, P., GuidelinesCPG, e. S. C. C. F. P. \& document, r. 2012. 2012 focused update of the ESC Guidelines for the management of atrial fibrillation: an update of the 2010 ESC Guidelines for the management of atrial fibrillation-developed with the special contribution of the European Heart Rhythm Association. Europace, 14, 1385-413.

Deora, S., Gurmukhani, S., Shah, S. \& Patel, T. 2014. Left Atrial Thrombus Causing Stroke and Syncope: Does Size Matters? Heart India, 2, 112-114.
Gupta, A., Bhatia, R., Sharma, G., Prasad, K., Singh, M. B. \& Vibha, d. 2015. Predictors of Ischemic Stroke in Rheumatic Heart Disease. J Stroke Cerebrovasc Dis, 24, 2810-5.

Ha, A. C., Verma, A. \& Verma, S. 2017. Oral anticoagulation for stroke prevention amongst atrial fibrillation patients with valvular heart disease: an update. Curr Opin Cardiol, 32, 174-180.

Healey, J. S., Oldgren, J., Ezekowitz, M., Zhu, J., Pais, P., Wang, J., Commerford, P., Jansky, P., Avezum, A., Sigamani, A., Damasceno, A., Reilly, P., Grinvalds, A., Nakamya, J., Aje, A., Almahmeed, W., Moriarty, A., Wallentin, L., Yusuf, S., Connolly, S. J., Registry, R.-1. A. F. \& cohort study, i. 2016. Occurrence of death and stroke in patients in 47 countries 1 year after presenting with atrial fibrillation: a cohort study. Lancet, 388, 1161-9.

Helgason, C. M. 1992. Cardioembolic stroke: topography and pathogenesis. Cerebrovasc Brain Metab Rev, 4, 28-58.

Lee, R. J., Bartus, K. \& Yakubov, S. J. 2010. Catheter-based left atrial appendage (LAA) ligation for the prevention of embolic events arising from the LAA: initial experience in a canine model. Circ Cardiovasc Interv, 3, 224-9.

Petersen, P \& Godtfredsen, J. 1988. Risk factors for stroke in chronic atrial fibrillation. Eur Heart J, 9, 291-4.

Phankingthongkum, R., Opartkiattikul, N., Chotinaiwattarakul, C., Panchavinnin, P., Tresukosol, D., Jakrapanichakul, D., Krittayaphong, R., Kitrattana, B. \& Thongtang, V. 2004. An abnormal systemic and regional hypercoagulable state in patients with mitral stenosis. J Med Assoc Thai, 87, 158-65. 


\section{QANUN MEDIKA \\ JURNAL KEDOKTERAN FK UM SURABAYA \\ http://journal.um-surabaya.ac.id/index.php/qanunmedika}

Pradhan, R. R., Jha, A., Nepal, G. \& Sharma, M. 2018. Rheumatic Heart Disease with Multiple Systemic Emboli: A Rare Occurrence in a Single Subject. Cureus, 10, e2964.

Topcuoglu, M. A., Liu, L., Kim, D. E. \& Gurol, M. E. 2018. Updates on Prevention of Cardioembolic Strokes. J Stroke, 20, 180-196.

Wang, D., Liu, M., Hao, Z., Tao, W., Lin,
S., Zhang, S., Wu, B., Ma, Z. \& Dong, W. 2012. Features of acute ischemic stroke with rheumatic heart disease in a hospitalized Chinese population. Stroke, 43, 2853-7.

Yusuf, J., Goyal, M., Mukhopadhyay, S., Mehta, V., Dhaiya, S., Saxena, R. \& Trehan, V. 2015. Effect of heart rate control on coagulation status in patients of rheumatic mitral stenosis with atrial fibrillation--A pilot study. Indian Heart J, 67 Suppl 2, S40-5. 